\title{
Zirconium Zr 89 Desferrioxamine B Monoclonal Antibody huJ591
}

National Cancer Institute

\section{Source}

National Cancer Institute. Zirconium Zr 89 Desferrioxamine B Monoclonal Antibody

hul591. NCI Thesaurus. Code C101133.

A radioimmunoconjug ate comprised of the recombinant humanized monoclonal antibody J591 against prostate-specific membrane antigen (PSMA) conjug ated to chelator desferrioxamine B (DFO-B) and labeled with the radioisotope zirconium $\mathrm{Zr} 89$ with potential imaging property used in positron emission tomography (PET) imaging. Upon administration of zirconium Zr 89 desferrioxamine B monoclonal antibody huJ591, the antibody moiety binds to the extracellular domain of PSMA, and the radioisotope moiety may be detected using PET, thereby allowing the imaging and quantification of PSMA-expressing tumor cells. PSMA, or folate hydrolase, is a cell surface peptidase highly expressed by malignant prostate epithelial cells and vascular endothelial cells of numerous solid tumor malignancies. In addition, upon PET imaging this agent provides high tumor:background tissue ratios. 